\title{
Muxes: between globalization and identity Impacts of new female models on gender performance
}

\author{
Ilaria Sartini \\ Universidad de Huelva
}

\begin{abstract}
Mass media and globalization allow ideas to travel to every corner of the world. When other people's ideas meet traditional cultures, in some cases they can result in cultural syncretism or in a resemantization of original practices. The images of hyperfemenized female bodies, broadcasted as successful women role models spreading from the West to the whole world, convey a subliminal heteronormative message and an exacerbated body "womanliness" normalized by beauty canons. These images have an impact on the Zapotec identities and bodies of the muxe ("third gender") in the state of Oaxaca, Mexico. More and more young muxes now want to change sex and «be real women». This has led to an increase in homosexual prostitution, in order to obtain the money to finance the operation, and to an increase in homophobia by both men and women in the Zapotec communities. By outlining some concepts such as sexuality, heteronormativity, globalization and introducing the figure of muxe in the Zapotec culture, the article aims at explaining the passage from muxe to transgender and its consequences in terms of gender performance and transphobia.
\end{abstract}

Key words: Gender identity; Globalization; Muxe; Transgender; Zapotec culture

\section{Brief introduction}

\section{Identity and globalization}

The identity that a person builds of itself is a mixture of different factors and perceptions, perceptive and intellectual instruments with which we filter reality, contexts, ideas and, experiences that define what we assume to be our identity. 


\section{5th International Conference on New Findings On HUMANITIES AND SOCIAL SCIENCES}

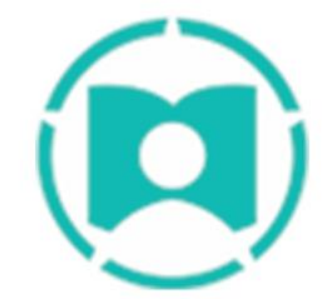

\section{0-22 NOVEMBER, 2020 PARIS, FRANCE}

By force of things, we assume sexuality as an important feature of our being and we give it much importance to define who we are, to this is added the socio-cultural context in which we grow and live and in this historical period, a very important part of our life and identity is shaped by the media, whether in the form of social networks, advertising or television. Gouldner (1978) and Giddens (2013) point out the importance of mass media as an important part of the creation of individual identity. Furthermore, Giovanni Sartori (Sartori, as cited in Rubio Ferreres, 2007, p. 115) points out how (in this case) television has turned the homo sapiens into homo videns, for whom the image has taken the place of the word and has led to a post-thinking video culture. Images show us and suggest who we could be, propose models of beauty, behavior, and ideology, and incite to appear and integrate ourselves among one of these (Rubio Ferreres, 2007).

In the global, interconnected world, ideas, inventions, images, and cultures travel to all corners, imposing themselves and mixing with the various indigenous cultures. Certainly, today we can find features of Western culture as in Bombay as in Mexico City, but we must also take into account that the native cultures tend to integrate these features in the pre-existing socio-cultural practices creating a process of heterogenization that in turn can create a juxtaposition between the modern and the traditional, the global and the local, the imported and the indigenous (Appadurai, 2001; ARCSHS, 2009). Globalization and mass media, as already mentioned, have an impact on the creation of individual identity, and what is worth noticing here is the impact on sexual identities. A selectivity and innovation regarding the appropriation of Western cultures and sexual identities have been found in non-Western cultures (ARCSHS, 2009). In particular, traditional models of homosexuality, being in contact with new identities and ways of thinking, create new sexual identities with new patterns and forms (Weeks, 2007). In this scenario, LGBTQI+ movements around the world have played a fundamental role in exporting new ways of thinking, despite the context in which one lives (ARCSHS, 2009) and the powerful media images that project us to what we could be. About this, the cosmetic and surgical industries play an important role in the way especially women are thought of. In recent years, more and more women, and not only, are turning to surgery to change their physical appearance and modulate it to get closer to ideal beauty models imposed by society. The consequences of this situation are described by Bourdieu in a very clear way: "the masculine domination, which turns women into symbolic objects, whose being (esse) is a perceived being (percipi), has the effect of placing them in a permanent state of corporal insecurity or, better said, of symbolic dependence" (1998: 86). Within the framework of gender performance, beauty, or rather, being beautiful, in Western culture is an important feature of being a woman. According to Wolf (2002), the ideology of beauty is a counter-blow of the patriarchal system to feminism. Indeed, since the beginning of the suffragist movements during the industrial revolution of the nineteenth century, the ideology of beauty has spread as an alleged characteristic of the female gender and because of a series of concomitant events created by the industrial revolution, women have embraced beauty as a feature of 


\section{5th International Conference on New Findings ON HUMANITIES AND SOCIAL SCIENCES}

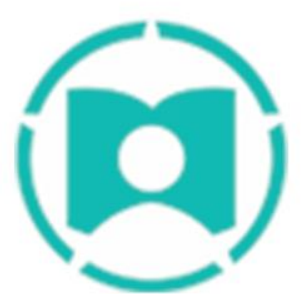

\section{0-22 NOVEMBER, 2020 \\ PARIS, FRANCE}

their identity. The visual discourse on women's bodies has evolved with increasingly extreme and normative rhetoric of women's bodies. Wolf argues that the ideology of beauty is the last bastion of the old ideologies about women, which has become stronger to replace the socially coercive work previously carried out by myths about motherhood, domesticity, chastity, and passivity. Together with this, the sexual revolution, if on the one hand, it has created women more conscious of their own body and their sexuality, on the other hand, it has created new vulnerabilities. The new relationship of freedom that is established between a woman and her body can be seen in relation and parallel to the rise of the pornography and fashion industries, and the consolidation of models of ideal beauty, undermining the new and vulnerable sense of sexual value that each woman attributes to herself. These industries have linked and commodified the idea of beauty with that of sexuality. Likewise, the models of successful women are related to beauty and youth, characteristics that are not required to men. In Mexico especially, the image of success is represented by mestizo people, with light skin color and European features, different from the phenotypical characteristics of most of the women in the state of Oaxaca, as it is one of the two states with the largest indigenous (Mexican Government, 2010) and afrodescendant population in the country (Mexican Government, 2015).

The hyper-sexualization of women's bodies and the Western beauty canons are sold to those who identify her self as a woman as two requirements for success and personal achievement. This has the power to affect teenagers as well as older sections of the population, all over the world (Ward, 2016).

\section{Muxe in the Zapotec culture}

Since pre-Columbian times, the concept of the third sex is or has been, found in several cultures, in addition to the male and female. The concept of "third gender" defined by some scholars as to the set of male and female characteristics that are ascribed to a single individual, is too narrow for the figure of the muxe, because, as noted by Miano Borruso (2001), this definition does not describe

[...] The complexity of roles, identities, contradictory interrelationships

between biology, sexuality, and gender. Above all, it hides that, in the

symbolic representation and the action scopes, the muxe is assigned to the

feminine scope mainly, since it is excluded from the masculine power scopes.

(p. 689)

In the Zapotec culture muxe, from the colonial Spanish mujer (woman), is the man who is sexually and emotionally attracted to men and who has relations with 


\section{5th International Conference on New Findings On HUMANITIES AND SOCIAL SCIENCES}

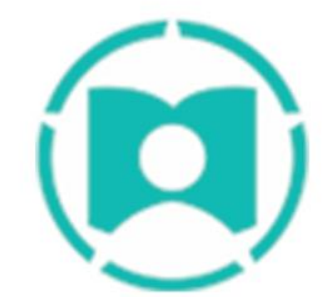

\section{0-22 NOVEMBER, 2020 PARIS, FRANCE}

heterosexual men passively. Men who are active in a homosexual sexual relationship (mayates), are considered and are seen as heterosexual because being the active part is seen as reaffirming the macho power. A muxe can also be a man who dresses like a woman, as occasionally as every day, or someone who feels like a woman but in a man's body and adopts attitudes, practices, and clothes of a woman, or can get married to a woman and still dressing with the typical woman-like muxe-dress, or someone who chooses to change sex and become a "whole" woman ("hacerse todo una mujer"), a fact that in the last twenty years has become more and more frequent among muxes (Miano Borruso, 2010; Islas Caro, 2013). From a young age, boys begin to acquire certain behaviors that are interpreted as their vocation to be a muxe (Gómez Jiménez, Semenya, and Valey, 2020). Depending on the family, the status, social class, and one's inclination to identify oneself in a certain way, the person will be a transvestite muxe or not. In the upper classes, muxes do not usually dress like women because power is still linked to masculinity, while in the working classes cross-dressing is tolerated.

There are two main features of being a muxe: not having sexual or emotional relationships with other muxes or people who define themselves as gay, and gender performance. If on the one hand the Zapotec culture is relatively open and inclined to the acceptance of these forms of non-heterosexual identities, on the other hand also among muxes gender is strictly performative (Bartolo Marcial, Miano Borruso and Gomez Suarez, 2009; Miano Borruso, 2010). Judith Butler defines the concept of gender performance implying that gender is a social practice that provides for the repeated and compulsory performance of certain attitudes and behaviors assigned to a gender, based on a system of punishment and rewards (Butler, 1988). Such social roles and behaviors consist of caring for the elderly and children, cleaning the house and the yard, cooking for the family, engaging in the trade of healer, designing and embroidering women's typical regional dress, making decorations, and participating in the organization of parties and religious festivities. Since the eighties, muxes have organized their vela (religious festivity), open to all citizens: the vela of the Authentic Fearless Seekers of Danger ("Auténticas Intrépidas Buscadoras del Peligro"). Another role that they recover is to initiate young Zapotec men to sexual practices. This happens because most girls have to arrive virgin to the first night of marriage and the prostitutes are usually economically out of boys' reach (Miano Borruso, 2001).

Although typical occupations of the male sphere, such as politics, cultural production, or professional art, are not usually performed by muxes (although things are changing now), they can manage to obtain a high family and social prestige that is built, as for women, in obtaining merit from the roles they play and can also inherit the social prestige of the mother or grandmother at her death, provided that the muxe has fulfilled all their responsibilities and expectations.

\section{The socio-cultural context of the Isthmus region}

The isthmus region is located in the South-Eastern part of the state of Oaxaca, Mexico. Here, since pre-Columbian times, live the Zapotecs, an ethnic group that 


\section{5th International Conference on New Findings On HUMANITIES AND SOCIAL SCIENCES}

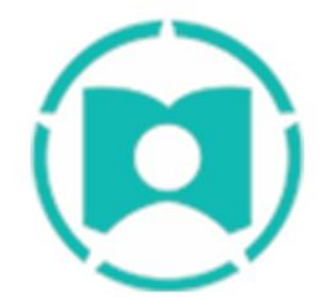

\section{0-22 NOVEMBER, 2020 PARIS, FRANCE}

counts with 500 thousand people (Joyce, 2014). In this region, like in all Mexico, the patriarchal macho structure takes place and reproduces in the daily life of the inhabitants of this territory but here there is a patriarchal "anomaly" because there is a certain economic and social protagonism of women. While we cannot talk about matriarchy, there is a distribution of roles that allows women to enjoy their social position (Ordaz, 2010). Power and social spaces are markedly defined according to the occupation performed in society and, differently than in other parts of Mexico, the scope of women's life is not restricted only to the home, but includes trade and the system of festivals and ceremonies as well. The market here becomes the place of women because it is their role to provide for the circulation and distribution of goods as well as the reproduction of the culture and tradition of their people through active participation in the organization of festivals, religious ceremonies, and festivities for which the Zapotecs are famous throughout Mexico. Despite the potential autonomy derived from their economic capacity and of the fact that the woman in her typical suit is the emblem of the Zapotec culture, the macho power is very strong and establishes conducts and attitudes that historically have left them out of the process of political participation and economic, intellectual and artistic production. Likewise, the supposed freedom enjoyed by muxes finds no parallel among lesbians (nguiu), and girls are required to prove their virginity by showing a blood-stained handkerchief after the first night of marriage (Miano Borruso, 2001).

Parallel to women's work, men are engaged in work in the fields or at sea or in the factory and are seen as natural repositories of political leadership. It is interesting to note how muxes, being men, can potentially frequent male spaces, although still getting involved in politics has occurred only a very few and recent cases, and being assiduous of female spaces in practice can exclude them from male spaces. Despite this, it is necessary to consider that, although in the Zapotec culture it is possible to speak of institutionalized homosexuality, the conquest, the colonialism, and the Catholicism, caused that the original sense of being muxe in the Zapotec society was lost and that a heteronormative system was imposed, causing homophobia, also in very violent forms, towards muxes (Chisholm, 2018).

It is interesting to see how in some families having a muxe son is something desired because, since he is not going to marry, he can take care of the parents when they will be old, he can help in the housework and at the same time work "like a man". Children's attitudes that do not correspond to the socio-cultural expectations of male and female are interpreted as a vocation to be a muxe and correspond to an assigned social destiny. Because of the advantages and help that mothers of muxe children receive, sometimes they themselves try to encourage these behaviors. In the history of acceptance and integration of muxes, women have played a fundamental role because they have given them support and shelter. Moreover, these strong and positive female models have represented a model to look up to, also for the muxes (Islas Caro, 2013). 


\section{5th International Conference on New Findings On HUMANITIES AND SOCIAL SCIENCES}

\section{(10) \\ 20-22 NOVEMBER, 2020 PARIS, FRANCE}

\section{Methodology}

This is mainly a theoretical essay developed partially during the fieldwork in Oaxaca between November 2018 and February 2019, and mostly after it.

This research wants to analyze the impact of globalization which, through media, spreads heteronormative rhetoric that can influence the way of perceiving our reality and ourselves, by answering the research question: "What are the dynamics behind the decision of many young people to prefer to become transgender in the muxe community of the Zapotecs of the state of Oaxaca, Mexico?" The study develops from a socio-anthropological standpoint and is based on the academic literature of authors who have extensively worked with the muxe community like Bartolo Marcial and Miano Borruso and authors who have developed sociological and socioanthropological theories concerning gender and sexualiy like Bourdieu, Boellstorff, Bornstein, Butler, Weeks and Wolf.

\section{Findings and results}

\section{Impacts on identities and bodies: from muxe to transgender}

\section{Identity}

In Zapotec culture, gender performance for muxes is fundamental for social recognition and is an integral part of their identity. Despite this, since the late 1990s, muxes of the Isthmus not only begin to cross-dress at an earlier age (between twelve and thirteen years old) but, as pointed out by the researchers' interviews, they want to undergo genital surgery to "be a real woman" (Bartolo Marcial, Miano Borruso and Gomez Suarez, 2009). These new identities take to the muxe community the discourse about gender transformation and binarism, already started by authors such as Butler (2007) and Bornstein (1994). Indeed, while for Butler the transformation from one gender to the other reproduces the heteronormative model because it is still within the binarism ideology, without going beyond it, for Bornstein the passage from male to female or from female to male is not necessarily to stay within the spectrum of gender but to engage transformation itself as the meaning of gender.

Probably, in addition to the more and more intrusive media and advertisement objectifying mestizo/Western women and depicting those bodies as successful, another cause of this new way of thinking within the muxe community could be the increasingly dominant role played by the LGBTQI+ movement on an international and national scale. Indeed, queer tourism, which has increased since the muxe group Autenticas Intrépidas Buscadoras del Peligro began broadcasting on the national television channel, has led to the arrival of journalists and activists who, in the press, defined the Isthmus region, generically and superficially, as a "queer paradise" (Bartolo Marcial et al, 2009; Chisholm, 2018). 


\section{5th International Conference on New Findings On HUMANITIES AND SOCIAL SCIENCES}

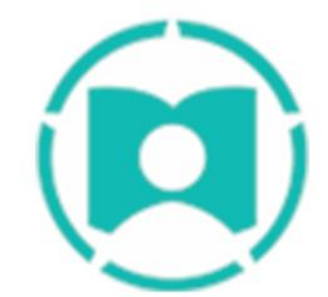

\section{0-22 NOVEMBER, 2020 PARIS, FRANCE}

To understand the consequences on the identity of the homosexual population impacted by globalization and Western models, Boellstorff (2003) uses the concept of dubbing culture to refer to his case study in Indonesia. Boellstorff notes how Indonesian gays and lesbians "dub Western [homosexual] subjects, just as it is done in the cinema or on television" (2003: 237), due to the great diffusion of Western pop culture in the country. The subjects of the target culture "dub" and at the same time reinterpret what comes from outside. It is a dialectic discourse between tradition and modernity that fuses in a Hegelian synthesis in something new that maintains united diverse cultural logic. What dub culture does is to show that the challenge between modernity and tradition is the translation of the colonization scheme: the paradigmatic values of the civilized colonizer over the tradition of the colonized (Boellstorff, 2003). Applying these concepts to the Zapotec culture, we realize that the first juxtaposition modernity-tradition is in the Spanish conquest, when the concept of muxe underwent a first great transformation because of the Spanish Church and the Inquisition and the second juxtaposition we are seeing it now, with the globalization and the exportation of Western models. In any case, this type of cultural and identity syncretism makes the muxes feel part of a global community and at the same time authentically Zapotec.

It is important to recall here the kind of sentimental and sexual relationship a muxe engages to: a relationship that is viewed as kind of , let's say, "heterosexual" (within its context) for the sake of labeling. Indeed, a muxe would not go with a man who identifies himself as homosexual or with another muxe, but generally with heterosexual men that are viewed from the rest of the population as heterosexual men, the mayates. This is important to understand what could be the dynamic that lies behind the willingness to become "a real woman" ("una mujer de verdad") among the youngest generations of muxes. A woman like the ones depicted in advertisement, television, and social media: extremely womanly, voluptuous, surrounded by men (or vice versa?), and unfailingly "retouched" by photoshop or the surgeon. What globalization, through heteronormativity and binary culture does, is to extremely simplify relationships. So that something as unidentifiable and fluid in the modern (non-traditional for the Zapotec culture) canons as the traditional concept of muxe, does not find its place in the projections of the self of younger generations.

\section{Body}

Muxes who want to change sex usually come from the working classes, because as mentioned earlier, transvestism is more tolerated than in the upper-middle classes. This means that the low individual resources are not enough to undergo the hormonal treatment before the operation and the operation itself. This has led to muxes using rubber bands to give their bodies a more feminine shape (Miano Borruso, 2010) and practicing unsupervised edible oil injections to make breasts, which is a clear risk to individual health. There has been also an increase in prostitution among the muxe community, supposedly to get money for genital surgery in a faster way (ibd.), as it 


\section{5th International Conference on New Findings On HUMANITIES AND SOCIAL SCIENCES}

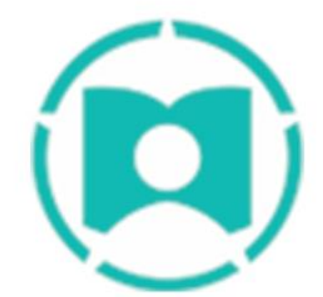

\section{0-22 NOVEMBER, 2020 PARIS, FRANCE}

happened in Europe in the eighties. However, even thou in Mexico there is no legal impediment to access the national health system, there are only two public clinics specialized in the treatment of transgender people and provide hormonal treatment and psychotherapy services. These two clinics are located in Mexico City and Monterrey, thousands of kilometers away from the state of Oaxaca. Also, genital operations are only performed by private urologists and plastic surgeons in Mexico City, Guanajuato, and Monterrey. There are only two public psychiatric centers and both are in Mexico City (Diehl et al., 2017). Moreover, it was only on 25th of May 2019, that the World Health Organization (WHO) had finally removed the gender dysphoria from the list of diseases (UN news, 2019), before this if one wanted the high costs of the operation being financed by the State, the person had to be diagnosed by a doctor as, "ill", suffering from gender dysphoria.

\section{Homophobia}

Parallel to the increase of sexual and identity freedom brought by globalization, homophobia has also been reinforced. This neo-homophobia is not only the answer of a part of the Zapotec population to the transvestism and the transgenders, but it originates mainly by the opposition between the definition given by some of the younger muxes when identifying themselves as "woman or more than a woman" and how part of the population described their behavior in some occasion as "men or almost men" (Bartolo Marcial et al. 2009). What these expressions show is an exacerbated transphobia. The discourse of this neo-homophobia/transphobia has been produced among women too, resulting in extreme acts such as the prohibition of access of transvestites to the vela of Juchitán de Zaragoza (Islas Caro, 2013). What the muxes are guilty of is precisely fulfilling their post-modern gender performance. Previously, the Catholicism and now the impacts of the globalization and the massive import of the heteronormative model in the Zapotec society, have influenced enormously in the Zapotec culture, so much that there is no place left to something as indefinite as the concept of traditional muxe, according to the heterosexist JewishChristian optics. From here the rhetoric of the discourse of a new gender performance that the community wants to impose on the muxes where, "if they want to be women, let them learn to behave like women. They do not behave like women and act like any man". Besides this, there is also a rejection by the men of the family who can use violence or move the family group away from the muxe. This is because Christian morality puts in the same and badly considered place to homosexuality, prostitution, and transvestism. Although in Mexico there are local and federal laws against sexual discrimination, muxes have been victims of transphobic crimes (Miano Borruso, as cited in Diehl et al., 2017, p. 390). The muxe community has called for recognition and support from international and local institutions and came together in a discourse of ethnic activism that reflects the perception that these crimes are not just crimes 


\section{5th International Conference on New Findings ON HUMANITIES AND SOCIAL SCIENCES}

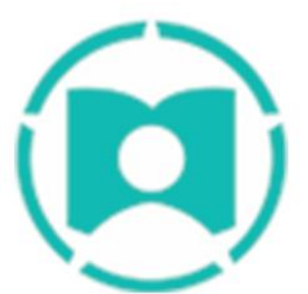

\section{0-22 NOVEMBER, 2020 PARIS, FRANCE}

against muxes but against the intangible Zapotec culture (Miano Borruso, as cited in Diehl et al., 2017, p. 392).

\section{Conclusions}

The concept of muxe and the muxes themselves are the protagonists of a semantic and social redefinition caused mainly by globalization and the massive importation of heteronormativity and Western models of beauty, far from the indigenous features of the Isthmus region. In the epoch of post-thinking, the homo sapiens becomes homo videns (Sartori, as cited in Rubio Ferreres, 2007, p. 115), subject to the massive and repetitive reproduction of concepts through evocative images. Beauty (only a certain kind of beauty thou) is used as an instrument to control and objectify women (Wolf, 2002), and to be able to reproduce those ideals of successful, young, and beautiful women that are seen in advertisements, social networks, magazines, movies, talk shows, soap operas, even in politics. This leads to a resemantization of "being a woman".These images of ideal women carry the subliminal message of heteronormativity: the eyes that look at them are not the eyes of other women, but the eyes of men. They embody ideals of beauty and above all sensuality that men desire. The woman's body is a "body-for-another" (Bourdieu, 1998).

A new meaning is added to the concept of muxe, being a (transgender) woman. This can be understood either as a strong repositioning of the concept of muxe within the binarism of gender (Butler, 2007) or as an expansion of the spectrum of gender itself (Bornstein, 1994). The fact that now younger muxes want to change sex, has led to an increase in homosexual prostitution to get the money to finance the operation, and an increase in homophobia by men as well as women (Miano Borruso, 2010). In the process of elaborating one's social identity related to one's sexuality, the precondition of social networks, and sexual communities that challenge the status quo and affirm the existence of these identities is fundamental. This implies the creation of cultures (gay culture, transvestite culture, femminielli culture, drag culture, etc.) that produce a new pluralism of gender and sexual experiences. These cultures confront the canonical, dominant culture that can generate forms of social antagonism with it, producing conflicts, such as homophobia (Weeks, 1998).

In such a context, just like any other, it would be extremely useful that school classes and workshops for the local community could be held about topics such as feminism and sexual and sentimental diversities, so to educate children and adults about patriarchal limits and to freedom of love. 


\section{5th International Conference on New Findings ON HUMANITIES AND SOCIAL SCIENCES}

\section{(10) \\ 20-22 NOVEMBER, 2020 \\ PARIS, FRANCE}

\section{References}

Appadurai, A. (2001). La modernidad desbordada. Buenos Aires, Argentina: Fondo de Cultura Económica.

Boellstorff, T. (2003). Dubbing culture: Indonesian gay and lesbi subjectivities and ethnography in an already globalized world. American Ethnologist, 30(2), 225-242.

Bornstein, K. (1994). Gender Outlaw. New York, NY: Routledge.

Bourdieu, P. (1998). La dominación masculina. Barcelona, Spain: Anagrama.

Butler, J. (1988). Performative acts and gender constitution: An essay in phenomenology and feminist theory. Theatre Journal, 40(4), 519-531.

Butler, J. (2007). Gender Trouble: Femmenism and the subversion of identity. New York, NY: Routledge.

Chisholm, J. (2018). Muxe, Two-Spirits, and the myth of Indigenous transgender acceptance. International Journal of Critical Indigenous Studies, 11(1), 21-35.

Australian Research Centre in Sex, Health and Society (ARCSHS). (2009). Globalization and transnational sexualities. Melbourne, Australia: Corboz J.

Diehl, A., Vieira, D. L., Zaneti, M. M., Fanganiello, A., Sharan, P., Robles, R., and De Jesus Mari, J. (2017). Social stigma, legal and public health barriers faced by the third gender phenomena in Brazil, India and Mexico: Travestis, hijras and muxes. International Journal of Social Psychiatry, 63(5), 389-399.

Giddens, A. (2013). The transformation of intimacy: Sexuality, love and eroticism in modern societies. New York, United States of America: John Wiley \& Sons.

Gomez Jimenez, F. R., Semenya, S. W., Vasey, P.L. (2020). The relationship between fraternal birth order and childhood sex-atypical behaviour among Istmo Zapotec muxes. Developmental Psychobiology, 62(1), 792-803.

Gouldner, A. W. (1978). The new class project. Theory and Society, 6(2), 153-203.

Mexican Government (2010). Informe sobre Desarrollo Humano de los Pueblos Indígenas en México. Mexico City, Mexico.

Mexican Government (2015). Datos de la Población Afrodescendiente en México. 


\section{5th International Conference on New Findings On HUMANITIES AND SOCIAL SCIENCES}

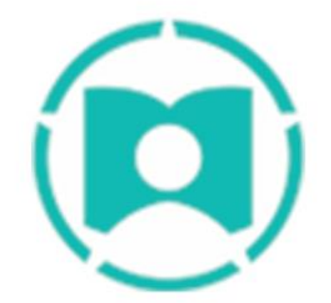

20-22 NOVEMBER, 2020

PARIS, FRANCE

Mexico City, Mexico.

Retrived from:

https://www.gob.mx/cms/uploads/attachment/file/199489/Datos_INEGI_poblacio_n_ afromexicana.pdf

Islas Caro, A. (Director). (2013). Muxes: auténticas, intrépidas y buscadoras de peligro [Anthropological Documentary]. Islas Caro.

Marcus, J. (2014). Monte Albàn. Mexico City, Mexico: Fideicomiso historia de las Américas.

Miano Borruso, M. (ed.) (2001). IV Congreso Chileno de Antropòlogos, Santiago de Chile, August, 2001. Colegio de Antropòlogos de Chile A. G.

Miano Borruso, M., Bartolo Marcial, E. and Gòmez Suárez, A. (ed.) (2009). XV Coloquio Internacional de Antropologìa Fìsica, Mérida, November 2009. Juan Comas.

Miano Borruso, M. (ed.) (2010). XIV Encuentro de Latinoamericanistas Españoles: 200 años de Iberoamérica (1810-2010), Santiago de Compostela, September 2010. Servicio de Publicaciòn e Intercambio Cientìfico.

Ordaz, P. (2010, June 20). Buscadoras del peligro. El Paìs. Retrived from https://elpais.com/diario/2010/06/20/eps/1277015216_850215.html

Rubio Ferreres, J. M. (2007). Las identidades en la era de la globalización mediática. Granada, Spain: Editorial Universidad de Granada.

UN health agency drops "gender identity disorder". (2019). Retrived from https://news.un.org/en/story/2019/05/1039531

Ward, L. (2016). Media and sexualisation. State of empirical research, 19952015. Journal of Sex, 53(4), 560-577.

Weeks, J. (1998). Sexualidad. Barcelona, Spain: Paidós Ibérica.

Weeks, J. (2007). The world we have won: The remaking of erotic and intimate life. New York, NY: Routledge.

Wolf, N. (2002). The beauty myth: How images of beauty are used against women. New York, NY: Harper Collins Publishers Inc. 